\title{
Pengembangan Permainan Edukatif Tebak Bendera Berbasis windows Phone
}

\author{
An'im Almikdad, Dr. R Rizal Isnanto, Ike Pertiwi Windasari \\ Program Studi Sistem Komputer Fakultas Teknik Universitas Diponegoro \\ Jalan Prof. Sudharto, Tembalang, Semarang, Indonesia
}

\begin{abstract}
There is still a lack of the use of technology in the learning process, so that the teachers are active only explain but the child passively because just listen and pay attention to the material presented. Conventional teaching methods result in children less excited and more easily bored in learning.

Theacer supposed to be able to utilize the technology to be applied in the learning process so as to enhance the child's enthusiasm for learning and teaching children to play an active role in learning. Based on these problems built an application Multimedia Interactive Learning based windows phone to be able to support the learning processin children.

The Learning Multimedia Applications built using software construct 2, and Adobe Photoshop cs5. The method used is a multimedia development Multimedia Development Life Cycle (MDLC). For application testing method using the Black Box Testand Likert Scale questionnaireform.
\end{abstract}

Key Terms : Technology developments, Flags, Game, Windows phone.

\section{PENDAHULUAN}

$\mathrm{T}$ EKNOLOGI merupakan alat atau sarana teknis yang digunakan manusia untuk meningkatkan perbaikan/penyempurnaan lingkungannya.

Teknologi di masa kini memberikan pengaruh yang sangat besar terhadap perkembangan masyarakat. Tidak jarang ditemukan masyarakat khususnya anak-anak sudah mahir bermain game di perangkat seluler. Melalui penelitian ini, penulis bermaksud membangun sebuah game interaktif bertema bendera dunia, untuk mengenalkan bendera serta lambang negara di dunia kepada masyarakat khususnya anak-anak dengan cara yang menyenangkan dan mudah diserap.

Dengan dilakukannya penelitian ini, diharapkan dapat menjadi salah satu media pembelajaran yang menyenangkan dan mudah dipahami bagi semua kalangan masyarakat sehingga, menggunakan gadget tidak hanya menggunakannya untuk bermain permainan umum, melainkan ada unsur pendidikan di dalamnya

\section{A. Multimedia}

\section{DASAR TEORI}

Menurut Vaughan (2004) multimedia merupakan kombinasi teks, seni, suara, gambar, animasi dan video yang disampaikan dengan komputer atau dimanipulasi secara digital dan dapat disampaikan dan/atau dikontrol secara interaktif ${ }^{[1]}$.

Ada tiga jenis multimedia, yaitu :

1. Multimedia interaktif

Pengguna dapat mengontrol apa dan kapan elemenelemen multimedia akan dikirimkan atau ditampilkan

2. Multimedia hiperaktif
Multimedia jenis ini mempunyai suatu struktur dari elemen-elemen terkait dengan pengguna yang dapat mengarahkannya. Dapat dikatakan multimedia jenis ini mempunyai banyak tautan (link) yang menghubungkan elemen-elemen multimedia yang ada.

3. Multimedia linear

Pengguna hanya menjadi penonton dan menikmati produk multimedia yang disajikan dari awal hingga akhir.

Menurut Hofstetter ${ }^{[2]}$, elemen-elemen yang terdapat pada multimedia secara umum terbagi atas lima jenis. seperti pada Gambar 1.

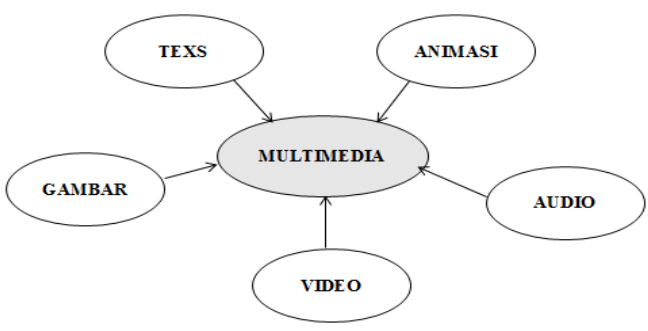

Gambar 1. Elemen multimedia.

1) Teks

Teks merupakan elemen multimedia yang menjadi dasar untuk menyampaikan informasi, karena teks adalah jenis data yang paling sederhana dan membutuhkan tempat penyimpanan yang paling kecil. Teks merupakan cara yang paling efektif dalam mengemukakan ide-ide kepada pengguna, sehingga penyampaian informasi akan lebih mudah dimengerti oleh masyarakat.

2) Grafik

Sangat bermanfaat untuk mengilustrasi informasi yang akan disampaikan terutama informasi yang tidak dapat dijelaskan dengan kata-kata. Jenis-jenis grafik seperti bitmap yaitu gambar yang disimpan dalam bentuk kumpulan pixel, yang berkaitan dengan titik-titik pada layar monitor.

3) Audio

Multimedia tidak akan lengkap jika tanpa audio (suara). Audio bisa berupa percakapan, musik atau efek suara.

4) Video

Video menyediakan sumber yang kaya dan hidup untuk aplikasi multimedia. Dengan video dapat menerangkan hal-hal yang sulit digambarkan lewat kata-kata atau 
gambar diam dan dapat menggambarkan emosi dan psikologi manusia secara lebih jelas.

5) Animasi

Animasi adalah simulasi gerakan yang dihasilkan dengan menayangkan rentetan frame ke layer. Frame adalah satu gambar tunggal pada rentetan gambar yang membentuk animasi.

\section{B. Permainan Edukatif}

Permainan Edukatif yaitu suatu permainan yang bermanfaat untuk menunjang proses tumbuh kembang, dan merupakan cara atau alat pendidikan yang bersifat mendidik bermanfaat untuk meningkatkan kemampuan berfikir. Dalam penyediaan mainan tidaklah harus mahal. Dengan kata lain, permainan edukatif dapat diberikan sejak lahir. Tentu semua menyesuikan dengan tumbuh kembang karena setiap masa memiliki tugas perkembangan masing-masing dan permainan tiap usia berbeda. ${ }^{[4]}$,

Permainan edukatif juga dapat berarti sebuah bentuk kegiatan yang dilakukan untuk memperoleh kesenangan atau kepuasan dari cara atau alat pendidikan yang digunakan dalam kegiatan bermain, yang disadari atau tidak memiliki muatan pendidikan yang dapat bermanfaat dalam mengembangkan diri secara seutuhnya.

\section{Sistem Operasi Windows phone}

Windows Phone adalah mobile OS yang dibuat dan dikembangkan oleh Microsoft yang sebelum sudah mempunyai OS mobile lain yakni Windows Mobile. Windows Phone merupakan adaptasi dari sistem operasi Windows 8 dengan konsep baru yang sebelumnya disebut Metro UI, tetapi kemudian menjadi simply modern. Ciri khas kotak-kotak pada layar home atau lebih dikenal dengan live tiles ini membuat Windows Phone terkesan simple dan dinamis.

\section{Microsoft Visual Studio}

Microsoft Visual Studio merupakan sebuah perangkat lunak lengkap (suite) yang dapat digunakan untuk melakukan pengembangan aplikasi, baik itu aplikasi bisnis, aplikasi personal, ataupun komponen aplikasinya, dalam bentuk aplikasi console, aplikasi Windows, ataupun aplikasi Web. Visual Studio mencakup kompiler, SDK, Integrated Development Environment (IDE), dan dokumentasi (umumnya berupa MSDN Library) ${ }^{[6]}$.

\section{E. UML (Unified Modelling Language)}

Pada perkembangan teknik pemrograman berorientasi objek, munculah sebuah standarisasi bahasa pemodelan untuk pembangunan perangkat lunak yang dibangun dengan menggunakan teknik pemrograman berorientasi objek, yaitu Unified Modelling Languange (UML). UML muncul karena adanya kebutuhan pemodelan visual untuk menspesifikasikan, menggambarkan, membangun, dan dokumentasi dari sistem perangkat lunak. UML merupakan bahasa visual untuk pemodelan dan komunikasi mengenai sebuah sistem dengan menggunakan diagram dan teks-teks pendukung. [7]

UML hanya berfungsi untuk melakukan pemodelan. Jadi penggunaan UML tidak terbatas pada metodologi tertentu, meskipun pada kenyataannya UML paling banyak digunakan pada metodologi berorientasi objek.
1) Diagram use case merupakan pemodelan untuk kelakuan (behaviour) sistem informasi yang akan dibuat. Diagram ini mendeskripsikan sebuah interaksi antara satu atau lebih aktor dengan sistem informasi yang akan dibuat. Secara kasar, use case digunakan untuk mengetahui fungsi apa saja yang ada di dalam sebuah sistem informasi dan siapa saja yang berhak menggunakan fungsi-fungsi itu.

Ada dua hal utama pada use case yaitu pendefinisian apa yang disebut aktor dan use case. Aktor merupakan orang, proses, atau sistem lain yang berinteraksi dengan sistem informasi yang akan dibuat di luar sistem informasi yang akan dibuat itu sendiri, jadi walaupun simbol dari aktor adalah gambar orang, tapi aktor belum tentu merupakan orang. Use case merupakan fungsionalitas yang disediakan sistem sebagai unit-unit yang saling bertukar pesan antar unit atau aktor.

2) Diagram sequence menggambarkan kelakuan objek pada use case dengan mendeskripsikan waktu hidup objek dan message yang dikirimkan dan diterima antar objek. Oleh karena itu untuk menggambar diagram sekuen, maka harus diketahui objek-objek yang terlibat dalam sebuah use case beserta metode-metode yang dimiliki kelas yang diinisiasi menjadi objek itu. Membuat diagram sekuen juga dibutuhkan untuk melihat skenario yang ada pada use case.

Banyaknya diagram sequence yang harus digambar adalah minimal sebanyak pendefinisian use case yang memiliki proses sendiri atau semua use case yang telah didefinisikan interaksi jalannya pesan sudah dicakup pada diagram sequence sehingga semakin banyak use case yang didefinisikan maka diagram sequence yang harus dibuat juga semakin banyak. ${ }^{[13]}$

\section{F. Skala Likert}

Skala Likert menurut Djaali (2008:28) ialah skala yang dapat dipergunakan untuk mengukur sikap, pendapat, dan persepsi seseorang atau sekelompok orang tentang suatu gejala atau fenomena pendidikan. Skala Likert adalah suatu skala psikometrik yang umum digunakan dalam kuesioner, dan merupakan skala yang paling banyak digunakan dalam riset berupa survei. ${ }^{[3]}$

\section{PERANCANGAN Sistem \\ A. Tahap Pengembangan Sistem}

Metodologi yang digunakan dalam penelitian ini adalah Multimedia Development Life Cycle (MDLC) yang bersumber dari Luther dan sudah dimodifikasi oleh Sutopo. Metodologi pengembangan multimedia tersebut terdiri dari enam tahap, yaitu konsep (concept), desain (design), pengumpulan materi (material collecting), pembuatan (assembly), pengujian (testing), dan distribusi (distribution). Keenam tahap ini tidak harus berurutan dalam prakteknya, tahap-tahap tersebut dapat saling bertukar posisi.

Metodologi pengembangan multimedia Luther yang telah dimodifikasi oleh Sutopo ini dapat dilihat pada Gambar 2. 


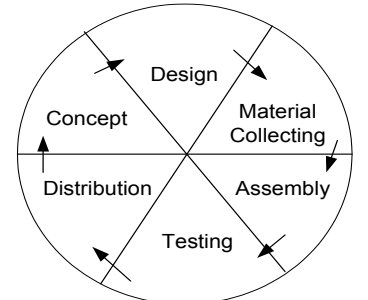

Gambar 2. Tahap pengembangan multimedia menurut Luther yang sudah dimodifikasi Sutopo

\section{B. Konsep}

Aplikasi yang dibuat dalam penelitian tugas akhir ini bertujuan untuk membuat simulasi dalam bentuk permainan tebak bendera. Objek penelitian ini memiliki kategori anak usia 8 tahun atau pada anak kelas 3 sekolah dasar (SD). Aplikasi ini tidak menutup kemungkinan untuk digunakan oleh semua umur.Konsep dasar aplikasi ini yaitu menarik dan dapat menjelaskan tentang berbagai macam bentuk serta warna yang ada pada di dunia. Oleh karena itu digunakan perpaduan teks, suara dan gambar dalam merancang desain aplikasi.

Permainan Edukasi tebak Bendera ini menyajikan tampilan beberapa bentuk, lambang dan warna yang ada pada di dunia. Permainan ini terdiri dari tiga tingkat kesulitan yaitu level 1, level 2,level 3. Pada setiap level user di ajak untuk menebak bendera-bendera yang ada dan mencocokanya dengan jawaban yang ada di setiap pilihan tombol yang tersedia dan tentunya dengan tingkat kesulitan yang berbeda-beda tergantung level mana user bermain, terdapat pewaktu yang mewajibkan user memelih jawaban yang ada pada tombol secepat mungkin karna permainan ini menggunakan waktu terbatas pada tiap-tiap levelnya .

Sebagai acuan pembuatan aplikasi pada tahap berikutnya maka disususn suatu skenario agar aplikasi yang dibuat sesuai dengan apa yang di harapkan.

1. Aplikasi " Tebak Bendera " terdiri dari halaman awal, halaman mulai, halaman cara bermain, dan halaman tentang.

2. Pada halaman awal user dapat melihat menu pilihan dari permainan Edukatif Tebak Bendara yang antaranya mulai bermain, cara bermain, dan tentang.

3. Halaman Mulai, user akan di hadapkan dengan 60 soal yang terdiri dari 30 soal berada di level 1, 20 soal berada di 2 dan 20 soal lainya berada di level 3 ,

dan untuk melanjutkan permainan user harus menjawab dengan benar soal-soal yang ada pada tiap level tersebut.

4. Halaman cara bermain, user akan dikenalkan tentang aplikasi "Tebak Bendara " dan cara memainkannya.

5. Halaman Tentang, user akan dikenalkan dengan fungsi dan kegunaan dari Permainan Edukatif "Tebak Bendara".

6. Aplikasi yang menggunakan Construct dan untuk keluar dari aplikasi ditambahkan tombol Keluar yang terdapat pada antar muka aplikasi

\section{Desain}

Desain proses dibuat berdasarkan kebutuhan fungsional dan kebutuhan data, Aliran Sistem digambarkan dengan menggunakan UML (Unified Modelling Language)
Diagram UML yang digunakan antara lain diagram use case, dan diagram sequence, Diagram use case menggambarkan fungsionalitas yang ditawarkan oleh sistem dan interaksi antara pengguna dengan sistem. Diagram sequence menggambarkan bagaimana objek saling berhubungan satu sama lain yang digambarkan sebagai rangkaian langkah-langkah yang dilakukan untuk menghasilkan keluaran tertentu.

\section{Use Case Diagram}

Use case diagram menggambarkan fungsionalitas yang diharapkan dari sebuah sistem. Use case menunjukan sebuah interaksi antara aktor dengan sistem. Komponen utama use case diagram ini adalah aktor dan use case. Pada aplikasi Tebak Bendera ini pengguna bertindak sebagai aktor yang menjalankan sistem. Use case diagram ditunjukan oleh Gambar 3. berikut:

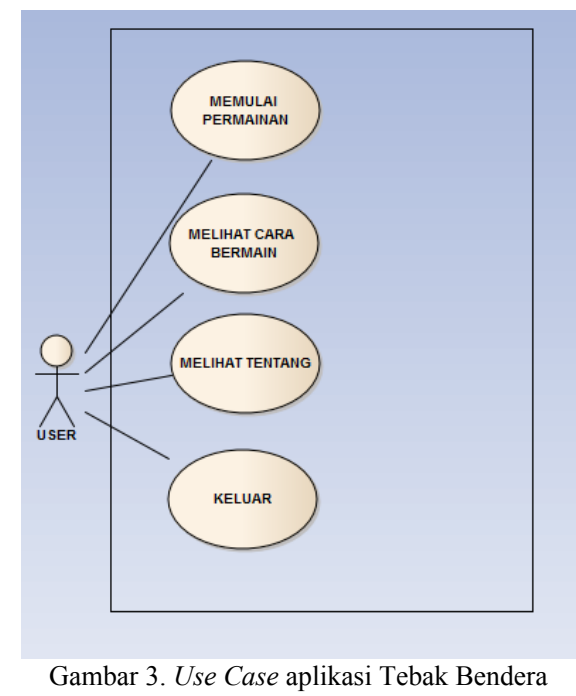

\section{Definisi Aktor}

Definisi Aktor berfungsi untuk mendeskripsikan peran aktor dalam aplikasi ini. Pada aplikasi yang akan dibangun ini hanya terdapat satu aktor yaitu user. user merupakan Aktor yang berperan dalam menggunakan aplikasi yang dibuat pada tugas akhir ini.

Definisi Use Case

Definisi Use Case berfungsi sebagai penjelasan mengenai proses yang terdapat pada setiap use case. Definisi use case dari Tugas Akhir ini akan dijelaskan pada Tabel I

Tabel I. Tabel Definisi Use Case

\begin{tabular}{|c|c|l|}
\hline No & $\begin{array}{c}\text { Nama Use } \\
\text { Case }\end{array}$ & \multicolumn{1}{|c|}{ Deskripsi } \\
\hline 1 & $\begin{array}{c}\text { Melihat } \\
\text { mulai }\end{array}$ & $\begin{array}{l}\text { user mengakses menu mulai } \\
\text { untuk masuk ke dalam } \\
\text { permainan pada level 1 }\end{array}$ \\
\hline & & $\begin{array}{l}\text { Fungsionalitas r yang } \\
\text { menampilkan 1 lambang } \\
\text { bendera dan user akan } \\
\text { mencocokkan jawaban yang } \\
\text { benar dengan 10 detik waktu } \\
\text { yang disediakan untuk } \\
\text { menebak 1 soal }\end{array}$ \\
& $\begin{array}{l}\text { Melihat } \\
\text { Permainan } \\
\text { level 1 }\end{array}$ \\
\hline
\end{tabular}




\begin{tabular}{|c|c|c|}
\hline 3 & $\begin{array}{l}\text { Melihat } \\
\text { Permainan } \\
\text { level } 2\end{array}$ & $\begin{array}{l}\text { Fungsionalitas } \\
\text { menampilkan } 2 \text { lambang } \\
\text { bendera dan user akan } \\
\text { mencocokkan jawaban yang } \\
\text { benar dengan } 20 \text { detik waktu } \\
\text { yang disediakan untuk } \\
\text { menebak 1 soal 1 }\end{array}$ \\
\hline 4 & $\begin{array}{l}\text { Melihat } \\
\text { Permainan } \\
\text { level } 3\end{array}$ & $\begin{array}{l}\text { Fungsionalitas } r \text { yang } \\
\text { menampilkan } 2 \text { lambang } \\
\text { bendera dan user akan } \\
\text { mencocokkan jawaban yang } \\
\text { benar dengan } 30 \text { detik waktu } \\
\text { yang disediakan untuk } \\
\text { menebak 1 soal }\end{array}$ \\
\hline 5 & $\begin{array}{c}\text { Melihat cara } \\
\text { bermain }\end{array}$ & $\begin{array}{l}\text { user mengakses menu cara } \\
\text { bermain untuk mengetahui } \\
\text { cara bermain dari aplikasi } \\
\text { Tebak bendera }\end{array}$ \\
\hline 6 & $\begin{array}{l}\text { Melihat } \\
\text { tentang }\end{array}$ & \begin{tabular}{l}
\multicolumn{3}{l}{ user mengakses menu tentang } \\
dan akan menampilkan \\
penjelasan dari Tebak \\
Bendera
\end{tabular} \\
\hline
\end{tabular}

\section{HASIL DAN PEMBAHASAN}

A. Hasil Pembuatan Aplikasi "Tebak Bendera"

Pembuatan aplikasi ini menggunakan metodologi pengembangan multimedia yang sudah dijelaskan pada bab sebelumnya. Terdapat 6 tahapan yang dilakukan untuk menyelesaikan aplikasi ini, yaitu konsep, desain, pengumpulan materi, pembuatan, pengujian dan distribusi.

Pembuatan aplikasi ini diimplementasi berdasarkan perancangan yang telah dibahas pada Bab III, sehingga dihasilkan suatu permainan yang bekerja sesuai dengan fungsinya. Sedangkan pengujiannya pada perangkat smartphone dilakukan dengan metode black-box, serta akan dilakukan juga uji coba permainan secara langsung ke pengguna menggunakan kuesioner. Berikut ini merupakan tampilan aplikasi yang telah dibuat

Gambar 4. menunjukkan tampilan menu utama dari aplikasi Tebak Bendera

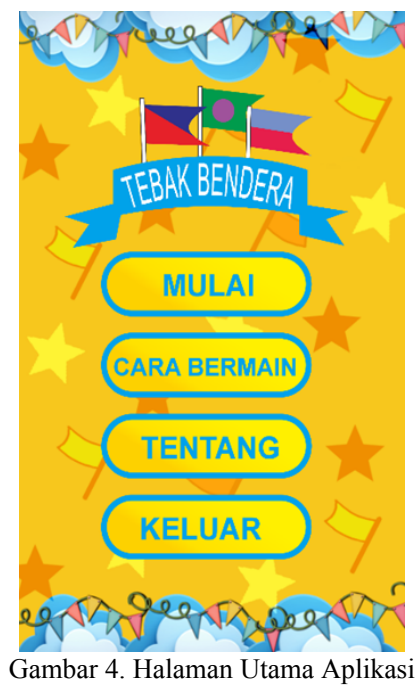

Selanjutnya gambar 5. menunjukkan tampilan level 1

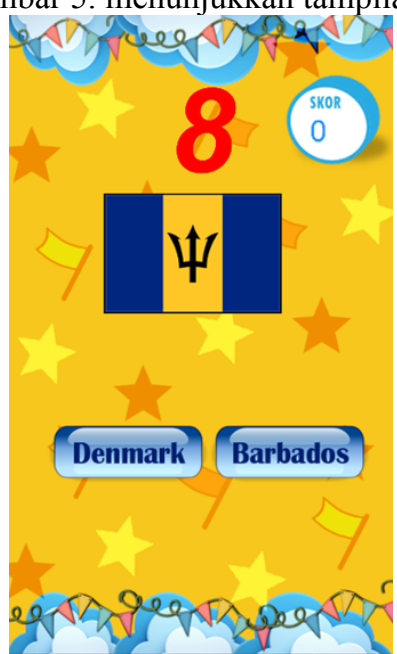

Gambar 5 Halaman permainan level 1

Gambar 6. menunjukkan tampilan Level 2

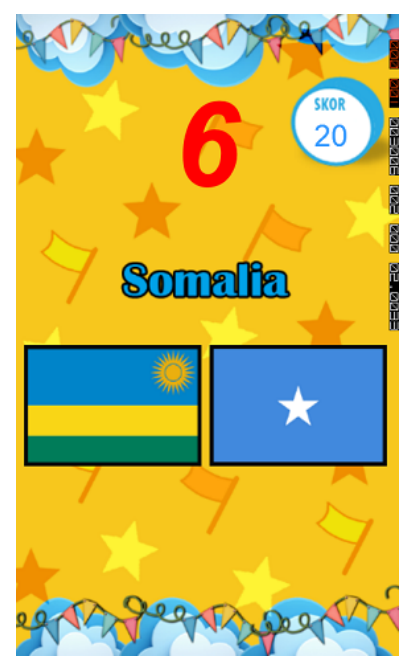

Gambar 6. Halaman permaina level 2

Gambar 7. menunjukkan tampilan Level 3

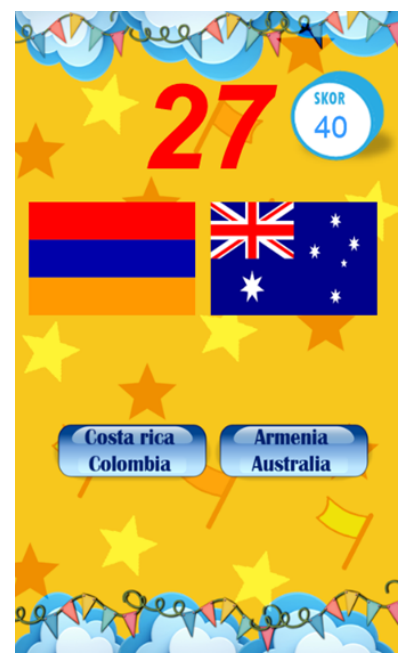

Gambar 7. Halaman permainan level 3 
Gambar 8. menunjukkan tampilan halaman waktu habis

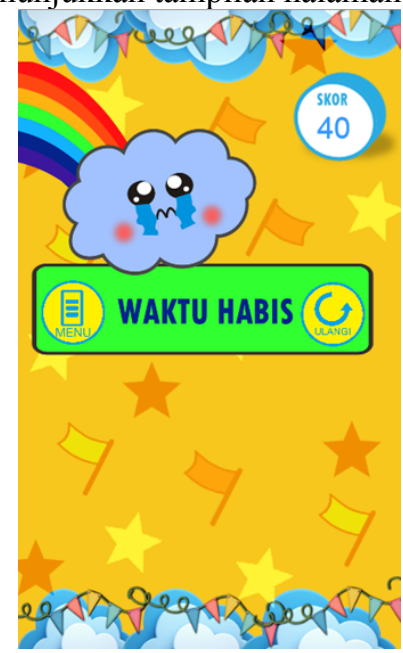

Gambar 8 Tampilan halaman waktu habis

Gambar 9. menunjukkan tampilan halaman pilihan salah

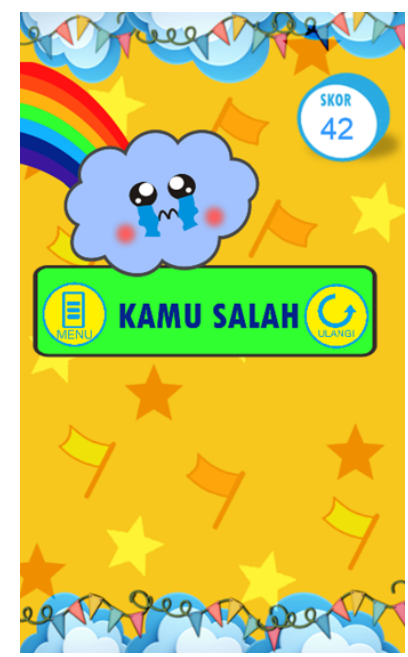

Gambar 9 Tampilan halaman pilihan salah

Selanjutnya pada gambar 10 menunjukkan tampilan permainan selesai

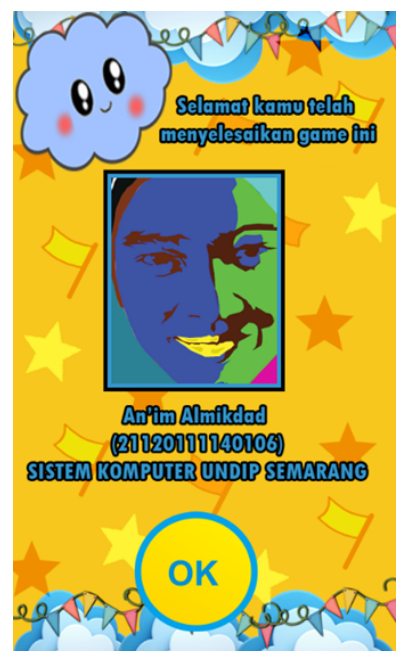

Gambar 10 Permainan selesai
Gambar 11 menunjukkan tampilan menu cara bermain dari aplikasi Tebak Bendera

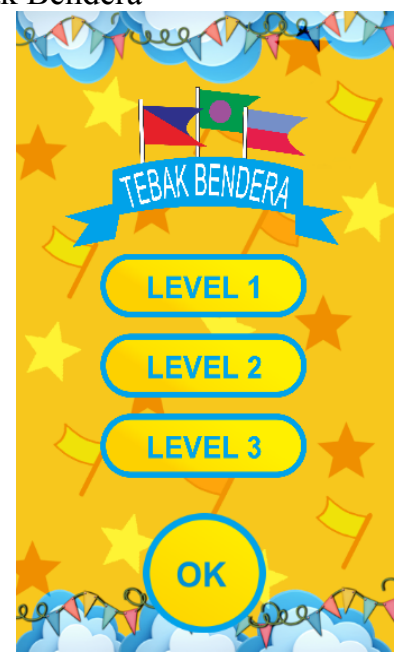

Gambar 11. Halaman bara bermain

Pada gambar 12. menunjukkan tampilan tentang dari aplikasi Tebak Bendera

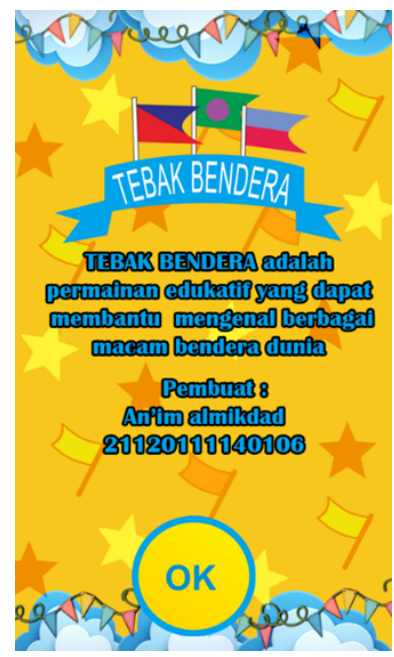

Gambar 12. Halaman Tentang

\section{Pengujian Aplikasi dengan metode Black-box}

Pengujian aplikasi "Tebak Bendera" yang telah dibuat dalam penelitian ini dilakukan dengan menggunakan metode black-box. Tahapan pengujian ini berisi rangkaian pengujian tombol dan fungsi yang terdapat dalam aplikasi. Pengujian ini dilakukan untuk memeriksa fungsi yang terdapat dalam aplikasi, apakah hasilnya sesuai dengan yang diinginkan. Pengujian ini juga dilakukan untuk mengetahui apakah masih terdapat kesalahan dalam aplikasi ataukah masih terdapat kesalahan sehingga secepatnya dapat diberi solusi.

Pengujian dijalankan pada smartphone dengan sistem operasi windows phone 8. Pengujian dilakukan dengan cara mengeksekusi souce code dan kemudian diamati apakah hasilnya sesuai dengan spesifikasi kebutuhan. Hasil dari pengujian aplikasi ditunjukkan dengan tabel-tabel pengujian black-box.

Berikut tabel pengujian pada fungsi umum aplikasi ditunjukkan oleh Tabel II. 
Tabel II. Tabel Pengujian Fungsi Umum

\begin{tabular}{|l|l|l|c|}
\hline \multicolumn{1}{|c|}{$\begin{array}{c}\text { Nama } \\
\text { Pengujian }\end{array}$} & $\begin{array}{c}\text { Bentuk } \\
\text { Pengujian }\end{array}$ & $\begin{array}{l}\text { Hasil yang } \\
\text { Diharapkan }\end{array}$ & $\begin{array}{c}\text { Hasil } \\
\text { Pengujian }\end{array}$ \\
\hline $\begin{array}{l}\text { Pengujian } \\
\text { menu mulai }\end{array}$ & $\begin{array}{l}\text { Menyentuh } \\
\text { tombol } \\
\text { mulai }\end{array}$ & $\begin{array}{l}\text { Tampil } \\
\text { halaman } \\
\text { permainan } \\
\text { level 1 }\end{array}$ & Berhasil \\
\hline $\begin{array}{l}\text { Pengujian } \\
\text { menu cara } \\
\text { bermain }\end{array}$ & $\begin{array}{l}\text { Menyentuh } \\
\text { tombol cara } \\
\text { bermain }\end{array}$ & $\begin{array}{l}\text { Tampil } \\
\text { halaman cara } \\
\text { bermain }\end{array}$ & Berhasil \\
mengujian \\
tentang
\end{tabular}

\section{Pengujian Aplikasi Menggunakan Kuesioner}

Pengujian aplikasi dilakukan secara langsung kepada sasaran aplikasi, yaitu kepada masyarakat umum. Pengujian dilakukan secara obyektif dengan tujuan mengetahui penilaian terhadap aplikasi yang telah dibuat. Dalam pelaksanaannya aplikasi ini dijalankan oleh masing-masing pengguna, kemudian diberikan kuesioner kepada pengguna yang digunakan untuk mendapatkan data responden tentang penilaian aplikasi yang telah dibuat.

Setiap responden akan diberi 4 sampel pertanyaan dimana setiap pertanyaan terdapat 5 pilihan jawaban, yaitu Sangat Tidak Setuju (STS), Tidak Setuju (TS), Netral (N), Setuju (S), Sangat Setuju (SS). Masing-masing jawaban diberi skor berurutan sampai 5 .

Untuk mencari nilai persentase dari masing-masing jawaban kuesioner, digunakan rumus skala Likert sebagai berikut:

$$
Y=\frac{X}{\text { skor ideal }} \times 100 \%
$$

\section{Keterangan :} $\mathrm{X}$

$=$ Jumlah frekuensi dikalikan dengan nilai kategori jawaban

Skor ideal $=$ Nilai tertinggi dikalikan dengan jumlah sampel

$\mathrm{Y} \quad=$ Nilai persentase yang dicari

Berikut ini adalah hasil persentase masing-masing jawaban yang sudah dihitung nilainya dengan menggunakan rumus di atas.

Pada Tabel III. Dapat dilihat hasil kuesioner dari pertanyaan 1 "Aplikasi Tebak Bendera sangat mudah dalam penggunaannya"
Tabel III. Tabel Pengujian Kuesioner Pertanyaan 1

\begin{tabular}{|c|c|c|c|c|}
\hline Pertanyaan & Keterangan & Skor & Responden & Skor $\times$ Responden \\
\hline \multirow{3}{*}{1} & STS & 1 & 0 & 0 \\
\cline { 2 - 5 } & TS & 2 & 0 & 0 \\
\cline { 2 - 5 } & N & 3 & 0 & 0 \\
\cline { 2 - 5 } & S & 4 & 5 & 20 \\
\cline { 2 - 5 } & SS & 5 & 5 & 25 \\
\hline \multicolumn{6}{c}{ Jumlah } \\
Y $=\frac{45}{40 \times 5} \times 100 \%=90 \%$ \\
\hline
\end{tabular}

Tabel IV. Dapat dilihat hasil kuesioner dari Pertanyaan 2 "Teks dalam permainan sudah jelas dan mudah dipahami"

Tabel IV. Tabel Pengujian Kuesioner Pertanyaan 2

\begin{tabular}{|c|c|c|c|c|}
\hline Pertanyaan & Keterangan & Skor & Responden & Skor $\times$ Responden \\
\hline \multirow{3}{*}{4} & STS & 1 & 0 & 0 \\
\cline { 2 - 5 } & TS & 2 & 0 & 0 \\
\cline { 2 - 5 } & N & 3 & 3 & 9 \\
\cline { 2 - 5 } & S & 4 & 6 & 24 \\
\cline { 2 - 5 } & SS & 5 & 1 & 5 \\
\hline \multicolumn{2}{|c|}{ Jumlah } & 10 & 38 \\
\hline
\end{tabular}

$$
\mathrm{Y}=\frac{38}{10 \times 5} \times 100 \%=76 \%
$$

Selanjutnya Tabel V. Dapat dilihat hasil kuesioner dari Pertanyaan 3 "Tampilan Aplikasi Tebak Bendera secara keseluruhan bagus dan menarik"

Tabel V. Tabel Pengujian Kuesioner Pertanyaan 3

\begin{tabular}{|c|c|c|c|c|}
\hline Pertanyaan & Keterangan & Skor & Responden & Skor $\times$ Responden \\
\hline \multirow{3}{*}{2} & STS & 1 & 0 & 0 \\
\cline { 2 - 5 } & TS & 2 & 0 & 0 \\
\cline { 2 - 5 } & N & 3 & 0 & 0 \\
\cline { 2 - 5 } & S & 4 & 7 & 28 \\
\cline { 2 - 5 } & SS & 5 & 3 & 15 \\
\hline \multicolumn{2}{|c|}{ Jumlah } & 10 & 43 \\
\hline
\end{tabular}

$$
\mathrm{Y}=\frac{43}{10 \times 5} \times 100 \%=86 \%
$$

Tabel VI. Dapat dilihat hasil kuesioner dari pertanyaan 4 "Setelah menggunakan aplikasi Tebak Bendera ini, anda lebih memahami berbagai macam bendera yang ada di dunia”, 
Tabel VI. Tabel Pengujian Kuesioner Pertanyaan 4

\begin{tabular}{|c|c|c|c|c|}
\hline Pertanyaan & Keterangan & Skor & Responden & Skor $\times$ Responden \\
\hline \multirow{5}{*}{5} & STS & 1 & 0 & 0 \\
\hline & TS & 2 & 0 & 0 \\
\hline & $\mathrm{N}$ & 3 & 0 & 0 \\
\hline & $\mathrm{S}$ & 4 & 8 & 32 \\
\hline & SS & 5 & 2 & 10 \\
\hline \multicolumn{3}{|c|}{ Jumlah } & 10 & 42 \\
\hline
\end{tabular}

Pada Tabel VII. Dapat dilihat hasil kuesioner dari pertanyaan 56 "Gambar dari bendera yang ditampilkan sudah jelas"

Tabel VII. Tabel Pengujian Kuesioner Pertanyaan 5

\begin{tabular}{|c|c|c|c|c|}
\hline Pertanyaan & Keterangan & Skor & Responden & Skor $\times$ Responden \\
\hline \multirow{4}{*}{6} & STS & 1 & 0 & 0 \\
\cline { 2 - 5 } & TS & 2 & 0 & 0 \\
\cline { 2 - 5 } & N & 3 & 0 & 0 \\
\cline { 2 - 5 } & S & 4 & 6 & 24 \\
\cline { 2 - 5 } & SS & 5 & 4 & 20 \\
\hline
\end{tabular}

$$
\mathrm{Y}=\frac{44}{10 \times 5} \times 100 \%=88 \%
$$

Nilai hasil kuesioner juga ditampilkan dalam bentuk diagram batang untuk mempermudah dalam melakukan analisis. Berikut merupakan diagram batang hasil penilaian aplikasi Tebak Bendera menggunakan kuesioner yang ditampilkan oleh Gambar 13.

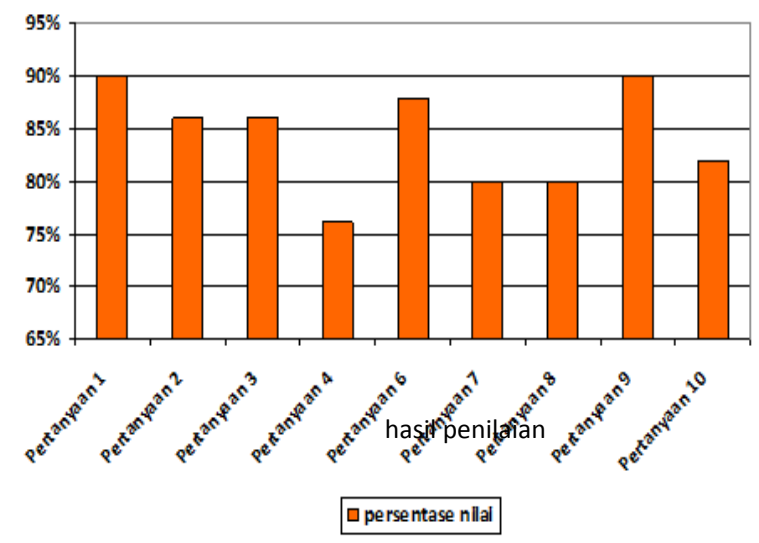

Gambar 13. Diagram batang hasil penilaian kuesioner

\section{B. Pembahasan}

Hasil pengujian aplikasi menggunakan metode black-box, menunjukkan bahwa permainan sudah berjalan sesuai dengan spesifikasi kebutuhan dan skenario aplikasi. Hal ini ditunjukkan oleh tabel 2 yang menampilkan hasil uji "Berhasil" pada tiap fungsi aplikasi dan tombol. Secara fungsional, aplikasi ini sudah dapat menghasilkan keluaran yang diharapkan.

Seperti dalam batasan masalah, bahwa permainan "Tebak Bendera" ini akan dijalankan pada sistem operasi Windows phone.

Berdasarkan hasil olah data kuesioner didapat skor ratarata dari semua pertanyaan yaitu sebesar $84 \%$. Hasil ini menunjukkan bahwa jawaban kuesioner berisi jawaban positif, atau dapat dikatakan aplikasi yang dibuat sudah berhasil dengan baik. Keseluruhan dari hasil olah data kuesioner dapat disimpulkan bahwa aplikasi yang dibuat telah memenuhi syarat untuk dianggap baik.

\section{KESIMPUlan DAN SARAN}

\section{A. Kesimpulan}

Dari hasil pengujian dan analisis permainan edukatif "Tebak Bendera" berbasis Windows Phone, dapat disimpulkan hal-hal yang diantaranya sebagai berikut.

1) Berdasarkan hasil pengujian aplikasi Tebak Bendera menggunakan metode Black-box, seluruh fungsi menu yang ada dalam aplikasi telah berhasil sesuai dengan fungsinya.

2) Berdasarkan hasil pengujian aplikasi Tebak Bendera menggunakan olahan data kuesioner menunjukkan bahwa 84,2\% lebih responden menjawab dengan jawaban positif atau dapat dikatakan aplikasi ini sudah berhasil dengan baik.

3) Pada tugas akhir ini pembuatan aplikasi menggunakna construct 2 .

4) Untuk dapat melakukan uji coba aplikasi "Tebak Bendera" pada perangkat windows phone dibutuhkan akun dreamspark dikarnakan windows phone sendiri yang bersifat close source.

B. Saran

Saran yang dapat diberikan oleh penulis dalam upaya pengembangan aplikasi lebih baik lagi di kemudian hari adalah sebagai berikut.

1) Perlu dilakukan penelitian lanjutan untuk mengembangankan aplikasi "Tebak bendera" menggunakan sistem operasi pada perangkat lain seperti Android, I phone, Blackberry dst.

2) Tampilan aplikasi "Tebak Bendera" hanya diam dan statis, diharapkan dapat ditambah efek animasi sehingga membuat aplikasi ini semakin menarik.

\section{DAFTAR PUSTAKA}

[1] Vaughan T., Multimedia:Making It Work, Edisi ke-6, New York: McGraw-Hill Companies, 2004

[2] Hofstetter, F. T., Multimedia Literacy, 3rd Edition, Irwin/MCGrawHill, 2011.

[3] Amirin, Tatang M. 2011. Skala Likert: PenggunaandanAnalisis Datanya. eprints.ums.ac.id/31837/16/7. DAFTAR PUSTAKA.pdf

[4] A Arsyad., Media Pembelajaran, Jakarta, PT Raja Grafindo Persada, 2003.

[5] ---, Construct 2, http://www.scirra.com 03 September 2014.

[6] ---, visuall studio http://www.microsoft.com 03 September 2014

[7] Grady Booch, Object-Oriented Analysis and Design with Application, Benjamin/Cummings, 1991. 